\title{
Dental Caries in Latin American and Caribbean countries: urgent need for a regional consensus
}

\author{
Fabio Correia SAMPAIO(a) \\ Zilson MALHEIROS $(b, c)$ (iD \\ Carlos BENÍTEZ(c) \\ Bernal STEWART ${ }^{(b, c)}$ \\ Marcelo BÖNECKER ${ }^{(c, d)}$ \\ (a) Universidade Federal da Paraíba - UFPB, \\ Health Science Center, Department of \\ Clinical and Community Dentistry, João \\ Pessoa, PB, Brazil. \\ (b) Colgate Palmolive Company, Colgate \\ Technology Center, Piscataway, NJ, USA. \\ (c)Latin American Oral Health Association, \\ LAOHA, São Paulo, SP, Brazil. \\ (d) Universidade de São Paulo - USP, School of \\ Dentistry, Department of Pediatric Dentistry, \\ São Paulo, SP, Brazil.
}

Declaration of Interests: The authors certify that they have no commercial or associative interest that represents a conflict of interest in connection with the manuscript. Zilson Malheiros and Bernal Stewart are currently employed by Colgate-Palmolive Company.

\section{Corresponding Author:}

Fabio Correia Sampaio

E-mail: fcsampa@gmail.com

https://doi.org/10.1590/1807-3107bor-2021.vol35.0057

Submitted: April 7, 2021

Accepted for publication: April 7, 2021

Last revision: April 9, 2021
Dental caries, a biofilm-mediated, sugar-driven, dynamic disease, affects a considerable proportion of children and adults worldwide. Recent reports indicate that the global burden of untreated dental caries for primary and permanent dentition is high in several countries and has remained relatively unchanged over the past 30 years. ${ }^{1,2,3}$

There is no doubt that Latin American and Caribbean countries (LACCs) are equally impacted by the burden of dental caries. However, to date, this area of the globe has never discussed dental caries in a comprehensive manner from a regional perspective. Many researchers have ignored the fact that Latin America is the most urbanized region in the world with severe social inequalities. ${ }^{4}$ Moreover, LACCs are responsible for approximately half of the global sugar production as well as known for their high sugar consumption. ${ }^{5}$ These aspects indeed impact the prevalence of dental caries in many parts of the continent, although salt and water fluoridation has been implemented in some areas of the region and fluoride dentifrice is available for a considerable part of the population. ${ }^{6}$

The Latin American Oral Health Association (LAOHA) is a nonprofit organization that has the following aims: a) foster the development of new researchers, b) influence oral health policy in the region, c) support the dental profession via education and exposure to new advances in dentistry, and d) encourage research initiatives in Latin America. Based on these principles, LAOHA established and mobilized a local network of experts in Cariology, Public Health, Epidemiology, Pediatric Dentistry, Restorative Dentistry, and other fields to explore dental caries in the following four domains: a) dental caries epidemiology and its impact on Oral Health Related Quality of Life, b) dental caries risk factors, ${ }^{7}$ c) dental caries preventive strategies, ${ }^{8}$ and d) dental caries (restorative) management. ${ }^{9}$ For each domain, an expert and the coauthors were asked to investigate reports, publications, and research on dental caries considering the complexity of the LACC environment and challenging strategies for tackling the problem.

In brief, the first draft of an article for each of the four domains was written during the first term of 2020 and reviewed by several invited experts from LACCs and the board members of international and regional dental associations. Later, these draft articles were presented and discussed in a virtual mode during the IADR (International Association for Dental Research) Brazilian meeting in September 2020. Several new points of discussion and suggestions from this meeting were incorporated 
in the second version of the article. Then, the final versions of the articles were shared for a second round of review by the same as well as new experts. Meanwhile, a fifth article presenting the summary as well as general and specific recommendations was also prepared and revised. ${ }^{10}$

The five articles were finally presented in November 2020 in the virtual consensus meeting held in Mexico, titled "Dental caries prevalence, prospects, and challenges for Latin American and Caribbean countries: A regional consensus." Following the meeting, a final review was performed by more than 110 stakeholders and experts from 22 countries enrolled in this initiative to achieve a consensus.

This consensus is a great achievement for LAOHA and all authors, reviewers, dental associations, and collaborators of this project. This special issue of Brazilian Oral Research was written in English. Moreover, Spanish and Portuguese versions will be available as e-books. It represents a year of challenging work that was completed in a virtual mode because of the coronavirus disease 2019 pandemic that imposed a virtual existence and changed the way we meet. This new scenario has brought both opportunities and challenges for LACCs with respect to future epidemiological surveys, dental assistance, and clinical and experimental studies.

Dental caries is preventable, and some international organizations have indicated potential solutions and recommendations. ${ }^{11-14}$ This raises the question why there is no substantial positive impact on reducing caries and inequalities in oral health in LACCs. These and other points of reflection are discussed in all papers of the consensus. We hope that this consensus will be regarded as "the end of the beginning." We believe that this would be a starting point for LACCs to reduce gaps in our epidemiological data on dental caries and thereby implement synchronized, well-planned regional actions that will make a difference and reduce the burden of dental caries in this part of the world in the near future.

\section{Acknowledgements}

This editorial is part of the consensus titled "Dental Caries Prevalence, Prospects and Challenges for LACCs: A regional consensus", was promoted by the Latin American Oral Health Association and Colgate Palmolive Co. with the support of the Federación Odontológica Latinoamericana, Sociedade Brasileira de Pesquisa Odontológica (SBPqO/Brazilian Division of International Association for Dental Research - IADR), and the participation of experts from the region, including representatives from national, regional and international dental associations. All participants had the opportunity to review the manuscript and make their own contributions.

\section{References}

1. Peres MA, Macpherson LM, Weyant RJ, Daly B, Venturelli R, Mathur MR, et al. Oral diseases: a global public health challenge. Lancet. 2019 Jul;394(10194):249-60. https://doi.org/10.1016/S0140-6736(19)31146-8

2. Bernabe E, Marcenes W, Hernandez CR, Bailey J, Abreu LG, Alipur V, et al. Global, regional, and national levels and trends in burden of oral conditions from 1990 to 2017: a systematic analysis for the Global Burden of Disease 2017 study. J Dent Res. $2020 ; 99(4): 362-73$. https://doi.org/10.1177/0022034520908533

3. Marcenes W, Kassebaum NJ, Bernabé E, Flaxman A, Naghavi M, Lopez A, et al. Global burden of oral conditions in 1990-2010: a systematic analysis. J Dent Res. 2013 Jul;92(7):592-7. https://doi.org/10.1177/0022034513490168

4. Ystanes M, Strønen IA, editors. The social life of economic inequalities in contemporary Latin America: decades of change. Springer Nature; 2018.

5. OECD, Food and Agriculture Organizationn of the United Nations. OECD-FAO agricultural outlook 2019-2028: special focus: Latin America. Rome: OECD-FAO; 2019[ [cited 2020 Oct 1]. Available from: http://www.fao.org/3/ca4076en/CA4076EN.pdf

6. Paiva SM, Abreu-Placeres N, Camacho MEI, Frias AC, Tello G, Perazzo MF, et al. Dental caries experience and its impact on oral health-related quality of life in Latin American and Caribbean countries. Braz Oral Res. 2021;35(suppl 1):e052. https://doi.org/10.1590/1807-3107bor-2021.vol35.0052 
7. Martignon S, Roncalli AG, Alvarez E, Aránguiz V, Feldens CA, Buzalaf MA. Risk factors for dental caries in Latin American and Caribbean countries. Braz Oral Res. 2021;35(suppl 1):e053. https://doi.org/10.1590/1807-3107bor-2021.vol35.0053

8. Ricomini Filho AP, Chávez BA, Giacaman RA, Frazão P, Cury JA. Community interventions and strategies for caries control in Latin American and Caribbean countries. Braz Oral Res. 2021;35(suppl 1):e054. https://doi.org/10.1590/1807-3107bor-2021.vol35.054

9. Pozos-Guillén A, Molina G, Soviero V, Arthur RA, Chavarria-Bolaños D, Acevedo AM. Management of dental caries lesions in Latin American and Caribbean countries. Braz Oral Res. 2021;35(suppl 1):e055. https://doi.org/10.1590/1807-3107bor-2021.vol35.0055

10. Sampaio FC, Bönecker M, Paiva SM, Martignon S, Ricomini Filho AP, Pozos-Guillen A, et al. Dental caries prevalence, prospects, and challenges for Latin America and Caribbean countries: a summary and final recommendations from a Regional Consensus. Braz Oral Res. 2021;35(suppl 1):e056. https://doi.org/10.1590/1807-3107bor-2021.vol35.0056

11. Early childhood caries: IAPD Bangkok Declaration. Int J Paediatr Dent. 2019 May;29(3):384-6. https://doi.org/10.1111/ipd.12490

12. FDI World Dental Federation. Police statement: caries. Geneva: World Dental Federation, 2020 [cited 2020 Oct 5]. Available from: https://www.fdiworlddental.org/policy-statement-classification/caries

13. Pitts N, Pow R. The Innovation and Translation Hub Towards Oral and Dental Health through Partnership: how can the oral health and dental industries benefit from enabling positive behaviour in caries prevention and control amongst patients and the public? London: King's College London; 2020.

14. World Health Organization. Ending childhood dental caries: WHO implementation manual. Geneva: World Health Organization; 2019. 